\title{
Evolutionary differentiation of the sister cyanobacterial genera Cyanospira Florenzano, Sili, Pelosi et Vincenzini and Anabaenopsis (Woloszyńska) MiLLER in response to extreme life conditions
}

\author{
Claudio Sili, Cristina Mascalchi \& Stefano Ventura*
}

National Research Council of Italy, Institute of Ecosystem Study, Firenze Unit, via Madonna del Piano 10, I-50019 Sesto Fiorentino FI, Italy; *corresponding authore-mail: stefano.ventura@ise.cnr.it

\begin{abstract}
To clarify the distinctiveness of the genus Cyanospira from the related genus Anabaenopsis, a morphological study of several undescribed strains of Cyanospira and an extensive phylogenetic analysis of Anabaenopsis and Cyanospira were performed.

Heterocytous cyanobacterial strains were isolated from natron salt samples from the Republic of Chad containing large numbers of dormant dry akinetes. Morphology, and the entire life cycle, from akinete germination to the development of mature vegetative forms, were documented. Cultures of Cyanospira, obtained from the germination of desiccated akinetes, were characterized by variable filament dimensions and coiling degrees. Akinete development in vegetative filaments was typically apoheterocytic; akinetes developed in chains continuously expanding along the filament; in old cultures, the whole filaments could be transformed into chains of akinetes. The development pattern of akinetes in Cyanospira was definitely different from that of Anabaenopsis.

Phylogenetic analysis was performed using the ARB and SILVA phylogenetic tools and databases. All publicly available sequences of strains belonging to the genera Anabaenopsis and Cyanospira, and sequences of our new strains, were compared with selected entries of Nostocaceae. The two genera Anabaenopsis and Cyanospira formed two phylogenetically coherent and well defined sister units, mostly related to the genus Nodularia. Inside the Anabaenopsis branch, a cluster exclusively composed by strains of A. elenkinii and another corresponding to A. nadsonii could be identified. Sequences of Cyanospira formed two distinct phylogenetic clusters, respectively corresponding to the species $C$. rippkae and $C$. capsulata. Sequences of the alkaliphilic species $A$. abijatae were found to be members of the $C$. rippkae subcluster.

As already known for halophilic cyanobacteria, also alkaliphilic cyanobacteria of the genus Cyanospira were phylogenetically separated from their mesophilic counterparts, classified under the genus Anabaenopsis. We support that the differentiation of sister genera in response to selective conditions of extreme environments is a well represented evolutionary mechanism in cyanobacteria.
\end{abstract}

Key words: Cyanospira, Cyanospira rippkae, Cyanospira capsulata, Anabaenopsis, akinete, extremophiles, Rift Valley, natron, sister genera, cyanobacterial phylogeny

\section{Introduction}

Along the eastern African Rift Valley between Kenya and Tanzania, a chain of closed alkaline soda lakes gives rise to particular ecological niches, dominated by high concentration of carbonates and very high $\mathrm{pH}$. While the Rift Valley soda lakes are the most thoroughly studied, several other similar highly alkaline environments can be found in Africa, as for example in Ethiopia, or Chad (Grant 2006). Due to peculiar environmental features like water chemistry, high evaporation rates up to desiccation, high temperature, precipitation of nutritional ions as $\mathrm{Ca}$ and $\mathrm{Mg}$, high light irradiance, and osmotic stress, those soda lakes represent truly extreme environments. Nevertheless, a composite microbial community, dominated by species of cyanobacteria, flourishes in their waters and along their shores. To cope with harsh living conditions, cyanobacteria of Rift Valley soda lakes have developed peculiar physiological and morphological adaptations (SILI et al. 1994). Among the diverse cyanobacteria found in those environments, the heterocytous genus Cyanospira with its two species $C$. rippkae Florenzano, Sili, Pelosi et Vincenzini and $C$. 
capsulata Florenzano, Sili, Pelosi et Vincenzini, was described from Lake Magadi by Florenzano et al. (1985); for their morphology, the two species resembled species of the cyanobacterial genus Anabaenopsis (WoloszyńsKa) Miller (KOMÁreK 2005), but clear differences were put in evidence. In this contribution we extend the knowledge on the genus Cyanospira by introducing new isolates from the Republic of Chad.

The duality Anabaenopsis-Cyanospira, with the former found in freshwater habitats and the latter exclusively colonizing hyperalkaline habitats, recalls of other sister clusters of cyanobacterial taxa, where one group colonizes extreme habitats while the other shows mesophilic aptitudes. One well described example is the Halothece (Garcia-Pichel, NüBel et MuYzer) Margheri, Ventura, Kaštovský et Komárek Cyanothece KomÁReK couple (MARGHerI et al. 2008), which, although being morphologically indistinguishable, have been shown to clearly diverge either at the physiological (MARGHERI et al. 1999) and phylogenetic level (GARCIA-PICHEL et al. 1998). Here we hypothesize that sister groups may arise as a consequence of adaptation to extreme environments and that this is a rather common pattern of evolution at least among cyanobacteria. In this view, we demonstrate the differentiation of the Anabaenopsis-Cyanospira sister clusters.

\section{Materials and Methods}

Strains of heterocytous cyanobacteria with coiled filaments described in this work were isolated from natron $\left(\mathrm{Na}_{2} \mathrm{CO}_{3} \cdot 10 \mathrm{H}_{2} \mathrm{O}\right)$ salt originating from the shores of closed hyperalkaline lakes located along the irregular north-eastern fringe of Lake Chad in the Republic of Chad. Cyclic phases of water evaporation and flooding cause salt precipitation around the lakes; the precipitate, called natron, was once used in the ancient Egyptian mummification process, and is presently harvested and commercialized in local markets as cattle feed and popular medicine. Samples of natron used in this work were obtained in 1996 from country markets located on the eastern shores of Lake Chad, Republic of Chad. For enrichment purposes, natron samples were dissolved in distilled water or in BG-11 ${ }_{0}$ medium and incubated in the light at $28{ }^{\circ} \mathrm{C}$ until a green cyanobacterial mass developed. Serial decimal dilutions of the enrichments were incubated in the light and strains of heterocytous cyanobacteria were isolated from the most diluted replicas which had turned green. Morphology of cells and filaments, akinete developmental pattern, akinete germination, and life cycle of the isolated strains were microscopically evaluated with a Nikon Eclipse E600 microscope. Morphometric data of vegetative cells, heterocytes, and akinetes were collected through a high resolution Nikon DS-5Mc camera head connected to the same microscope and elaborated with the Nikon NIS-Elements imaging software. The same set of microscopic observations and morphometric measures was carried out on strains Cyanospira capsulata CCAX, Cyanospira capsulata CC87E, C. rippkae CR86F5, and C. rippkae CR86F7 previously isolated from Lake Magadi (Kenya). Except for heavy rain periods, the central part of lake Magadi consists of a thick deposit of trona $\left(\mathrm{NaHCO}_{3} \cdot \mathrm{Na}_{2} \mathrm{CO}_{3} \cdot 12 \mathrm{H}_{2} \mathrm{O}\right)$ some hundred metres deep.

For cultivation of isolated cyanobacterial strains, Zarrouk medium without nitrate (ZARROUK 1966) was always used. Cultures were incubated at 28 ${ }^{\circ} \mathrm{C}$ with agitation in a Gallenkamp Orbital Incubator, in an atmosphere enriched with $4 \% \mathrm{CO}_{2}$, and exposed to a light/dark cycle of $14 / 10$ hours. Biomasses were harvested by centrifugation and the pellet fractions washed with standard saline solution $(0.1 \% \mathrm{w} / \mathrm{v})$, twice or more in case of mucilaginous cultures; pellets were divided into aliquots $(\approx 30 \mathrm{mg})$ and stored at $-20{ }^{\circ} \mathrm{C}$ until needed.

For DNA extraction, pellets were thawed and treated with PowerPlant DNA Isolation Kit, according to the manufacturer's protocol (MoBio Laboratories Inc.). In vitro amplification of a fragment of the cyanobacterial ribosomal operon including the nearly complete $16 \mathrm{~S}$ rRNA gene and the ITS, and sequencing of the $16 \mathrm{~S}$ rRNA gene was performed as thoroughly described in Cuzman et al. (2010); for each sequenced strain, three single reads were aligned in a unique consensus sequence using the software suite PHRED, PHRAP CONSED developed at the University of Washington (GORDON 2004). Using the SINA webaligner available on the SILVA website at http://www.arb-silva.de (PRUESSE et al. 2007), the public domain was searched for the nearest relatives of the newly obtained sequences and the complete sequence set was automatically aligned. The alignment file was downloaded and imported in ARB, a software environment for sequence data (LuDwiG et al. 2004), where it was visually inspected and manually edited. Phylogenetic relationships of the sequences were calculated with ARB on an rRNA gene fragment approx 1306 base pairs long in Cyanospira, corresponding to position 103 to position 1445 of the reference Escherichia coli gene region. Sequences of Cyanospira were added to a large alignment of Nostocaceae including six sequences of Anabaenopsis abijatae, 15 sequences of other Anabaenopsis spp., 62 sequences of Nodularia spp., and 377 sequences of other Nostocaceae. Sequences of Chroococcidiopsis thermalis PCC 7203 and of Nostoc elgonenese TH3S05 have been used to root the phylogenetic trees. Using 
Table 1. Origins and main morphometric data of Cyanospira capsulata strain Mag I 504 and C. rippkae strain Mag II 702 compared with data of newly studied strains of Cyanospira spp.

\begin{tabular}{|c|c|c|c|c|}
\hline \multirow[b]{2}{*}{ Strain } & \multirow[b]{2}{*}{ Origin } & \multicolumn{3}{|c|}{ Cell width $(\mu \mathrm{m})$} \\
\hline & & Vegetative cells & Heterocytes & Akinetes \\
\hline Cyanospira capsulata Mag I 504 & $\begin{array}{l}\text { Lake } \\
\text { Magadi } \\
\text { (Kenia) }\end{array}$ & $6.0-7.0$ & $8.0-8.5$ & $9-10.0$ \\
\hline Cyanospira rippkae Mag II $702^{\S}$ & “ & $4.0-5.0$ & $7.0-8.0$ & $9-9.5$ \\
\hline Cyanospira capsulata CCAX & “ & $6.2-6.9$ & $7.8-8.5$ & $8.8-9.8$ \\
\hline Cyanospira capsulata CC87E & “ & $6.4-7.1$ & $7.6-8.6$ & $8.7-9.5$ \\
\hline Cyanospira rippkae CR86F5 & “ & $6.1-6.3$ & $7.0-8.0$ & $7.9-8.5$ \\
\hline Cyanospira rippkae CR86F7 & “ & $6.0-6.4$ & $7.5-8.4$ & $8.1-9.0$ \\
\hline Cyanospira sp. NMBCl & $\begin{array}{l}\text { natron } \\
\text { (Chad) }\end{array}$ & $6.8-7.4$ & $7.8-8.9$ & $9.0-10.1$ \\
\hline Cyanospira sp. 5NR8 & “ & $6.1-6.5$ & $6.5-7.5$ & $7.0-9.0$ \\
\hline Cyanospira sp. 7NR8 & “ & $6.0-6.4$ & $6.4-7.2$ & $7.0-9.0$ \\
\hline Cyanospira sp. 8NR8 & “ & $6.0-6.5$ & $6.5-7.0$ & $7.0-9.0$ \\
\hline Cyanospira sp. NR3Af & “ & $6.8-8.0$ & $7.8-8.1$ & $9.0-11$ \\
\hline Cyanospira sp. 9NAT & “ & $6.8-7.2$ & $7.7-9.8$ & $8.0-10.2$ \\
\hline
\end{tabular}

t: the original description of the genus Cyanospira and of the species C. capsulata (Florenzano et al. 1985) has been based on this strain isolated in 1981.

§: the original description of the species C. rippkae (FLORENZANO et al. 1985) has been based on this strain isolated in 1982.

ARB, a first Neighbor-Joining (NJ) tree has been inferred using the complete set of 472 sequences. In a following step, the number of entries has been reduced to match calculation constrains and a smaller alignment including only Cyanospira spp., Anabaenopsis spp., and 20 sequences of Nodularia spp. has been used. NJ, Maximum Likelihood (ML), and Maximum Parsimony (MP) methods of phylogenetic inference, as made available in ARB, have been applied to obtain phylogenetic trees. NJ and MP trees have been bootstrapped 1000 or 100 times respectively.

\section{Results}

\section{Origin of the cyanobacterial isolates}

Strains of heterocytous cyanobacteria described in this work (Table 1) have been isolated from natron that accumulates on the shores of the numerous hyperalkaline ponds characterizing the eastern fringe of Lake Chad, Republic of Chad. The presence of dormant akinetes has been microscopically evidenced in the natron samples used in this study (data not shown). The isolated cyanobacteria have been therefore considered as representatives of the cyanobacterial population living in the hyperhalkaline ponds of the eastern Lake Chad region.

\section{Morphology}

All the studied cyanobacterial strains (Fig. 1) possessed a more or less regular coiled filamentous morphology. A dense, colourless mucilaginous capsule, 15-20 $\mu \mathrm{m}$ wide, evidenced by a negative staining with Indian ink, surrounded the trichomes of strains $C$. capsulata CCAX, $C$. capsulata CC87E and Cyanospira sp. 9NAT. In all examined strains, vegetative cells were shortly cylindrical, constricted at the cross-walls, and with numerous aerotopes. The heterocytes, always single, were usually situated in more or less regular distance in the apical and intercalary position. The akinetes were spherical, in very long rows, at first 

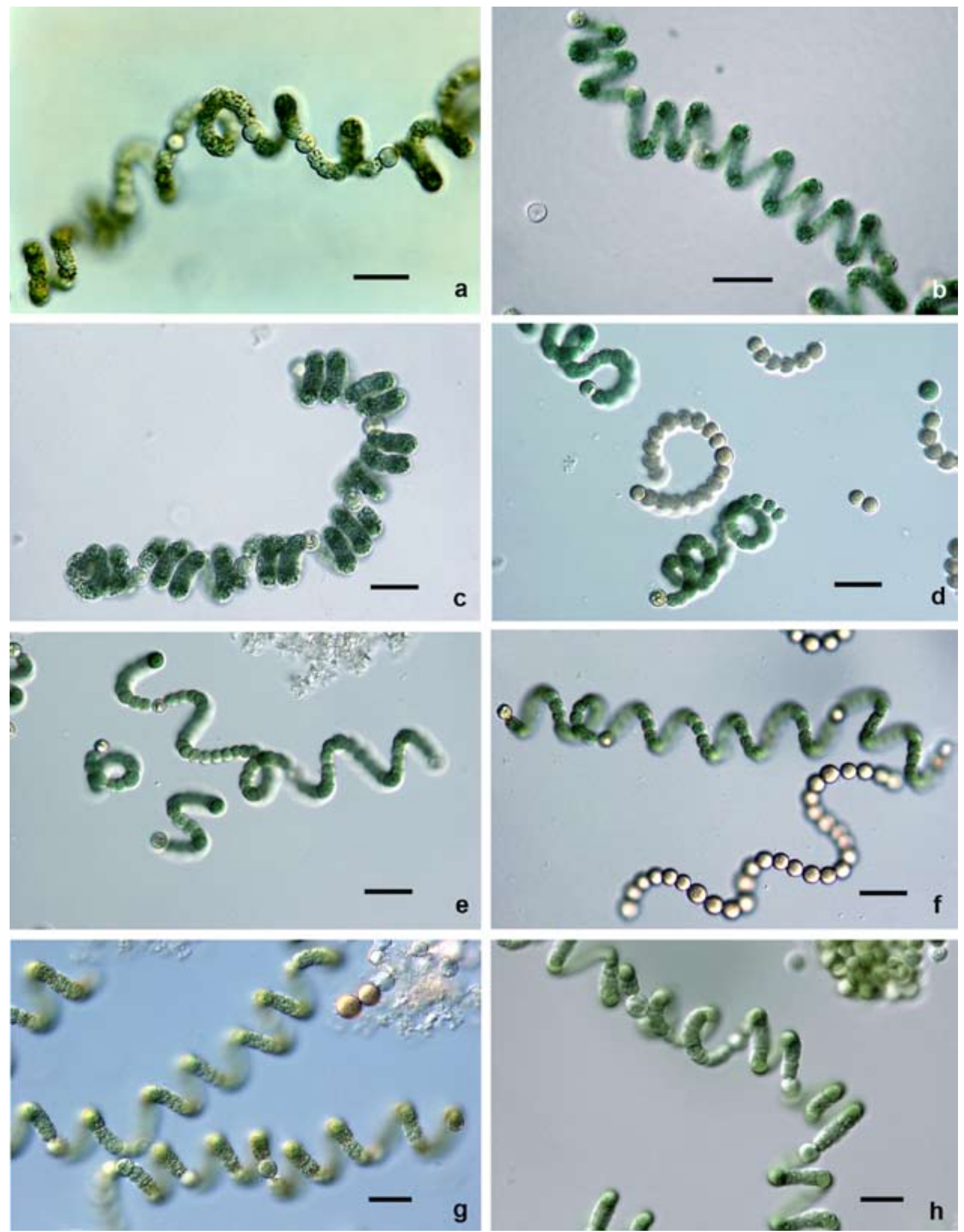

Fig. 1. Morphology of strains of Cyanospira spp. isolated from hyperalkaline lakes of the Rift Valley (Kenya) (a-b) and from natron (Republic of Chad) (c-h): (a) Cyanospira capsulata CCAX; (b) Cyanospira rippkae CR86 F5; (c) Cyanospira sp. NMBCl; (d) Cyanospira sp. 5NR8; (e) Cyanospira sp. 7NR8; (f) Cyanospira sp. 8NR8; (g) Cyanospira sp. NR3Af; (h) Cyanospira sp. 9NAT. Scale bar $20 \mu \mathrm{m}$ 



Fig. 2. Morphological features of Cyanospira spp.: (a) Cyanospira capsulata Mag I 504 negatively stained with Indian ink ; (b) Cyanospira rippkae Mag II 702; copious presence of aerotopes highlighted by the dark field in (c) Cyanospira capsulata Mag I 504 and (d) C. rippkae Mag II 702; (e-f) apoheterocytic pattern of akinete development in C.capsulata; (g-h) complete transformation of vegetative cells into akinetes in Cyanospira sp. NMBCl. Scale bar $20 \mu \mathrm{m}$. 
granulated and dark green and later brown; akinetes always showed an apoheterocytic developmental pattern characterised by a progressive maturation of vegetative cells located in the middle of the filament between two heterocytes. Morphometric data of vegetative cells, heterocytes and akinetes of the newly studied strains, compared with the data of the original isolates Cyanospira capsulata strain Mag I 504 and C. rippkae strain Mag II 702, are given in Table 1.

\section{Pattern of akinete differentiation}

Since a key feature of the genus Cyanospira is the mode of akinete development, the life cycle of $C$. capsulata (Figs 2a, 2c) and C. rippkae (Figs $2 \mathrm{~b}, 2 \mathrm{~d}$ ) was investigated in liquid cultures and the principal stages of akinete development documented by photomicrography. All new strains possessed the typical apoheterocytic pattern of akinete differentiation which constitutes one of the major characters differentiating Cyanospira from Anabaenopsis (KOMÁreK 2010). Unlike Anabaenopsis, where the akinete generally develop solitary or in pairs in a distant paraheterocitic position, in the studied strains the akinete development was found to follow the typical apoheterocytic pattern of Cyanospira, shown in Fig. 2 e-f. In the final stage of growth (Fig. 2 g-h), when cultures were very old and exhausted, the entire filaments had developed into chains of akinetes, a morphological adaptation to the unfavourable life conditions of hyperalkaline habitats obtained through the massive production of resting cell forms (SILI et al. 1994).

\section{Pattern of akinete germination}

The ability to rapidly germinate and the persistent vitality of these resting cells, the akinetes, was demonstrated in the cyanobacterial strains isolated from natron through the evaluation of their germination potential after three years of

Fig. 3. Germination of desiccated akinetes of C. capsulata inoculated after seven years into fresh liquid liquid medium under continuous illumination: (a) brown coloured akinete at $\mathrm{t}=0$; (b) appearance of green pigmentation at $\mathrm{t}=4-5 \mathrm{~h}$; (c) polar degradation of the akinete envelope; (d) outburst of the undivided cell, surrounded by the capsule (negatively stained with Indian ink), from the broken akinete coat; (e) first cell division at $\mathrm{t}=9-10 \mathrm{~h}$; (f) differentiation of the third vegetative cell at $\mathrm{t}=13-14 \mathrm{~h} ;(\mathrm{g})$ differentiation of the first proheterocyte at $\mathrm{t}=14 \mathrm{~h}$; (h) differentiation of the first heterocyte at $\mathrm{t}=18$ $21 \mathrm{~h}$; (i) beginning of trichome coiling. Scale bar $10 \mu \mathrm{m}$.



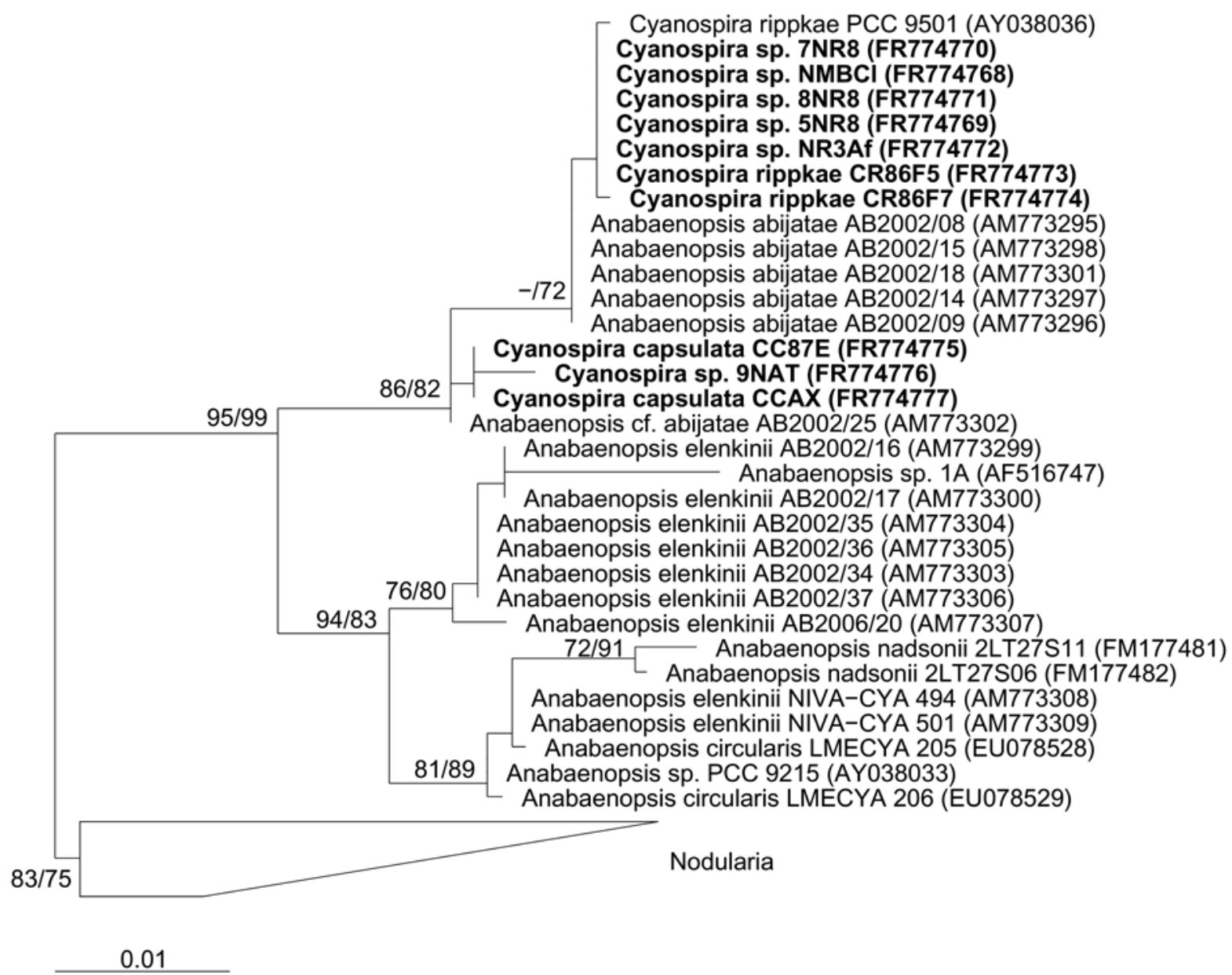

Fig. 4. Consensus phylogenetic tree of the sister genera Cyanospira and Anabaenopsis, based on 16S rRNA gene sequences. Sequences were analysed with NJ, MP, and NL methods. Percentages at nodes indicate bootstrap values of NJ and MP analysis, respectively. In bold: new strains of Cyanospira spp. studied in this work. Sequence accession numbers are given in parenthesis. Scale bar represents 0.01 substitution per nucleotide position.

conservation in dry conditions. All isolated strains were able to regain active vegetative conditions after less than 24 hours of incubation of their respective akinetes. For all investigated strains, the observed germination pattern fully corresponded to that shown in Figure 3 for C. capsulata, once desiccated akinetes were transferred into fresh liquid medium under continuous illumination. In those incubation conditions more than 90 $\%$ of the akinetes germinated. During the first $24 \mathrm{~h}$ of incubation, the germination was highly synchronous (SILI et al. 1994). Within the initial 4-5 h, the brown dormant akinetes (Fig. 3a) assumed a turgid appearance and turned green (Fig. 3b). Between the eighth and the ninth hour, with the increase of cell turgor, rupture of the akinete coat took place (Fig. 3c) and the undivided cell, surrounded by a capsule, emerged from the broken akinete coat (Fig. 3d). 9-10 h after starting the rehydration of the akinetes, the germling completed the first cell division (Fig. 3e) and at around hour 13-14 it completed the third division (Fig. 3f). Soon after, around the 14th hour, the germling differentiated the first proheterocyte (Fig. 3g), which matured into the first heterocyte between hour 18-21 (Fig. 3h). After 24-25 h from the beginning, the young trichomes ended the period of synchronous growth, and the elongation and coiling process began (Fig. 3i).

The viability of akinetes of Cyanospira was remarkable: recently, desiccated akinetes of $C$. capsulata stored in the the dark in our laboratory for twenty five years, when transferred to liquid Zarrouk medium without nitrate under continuous illumination began to germinate within $40-50$ hours (data not shown).

\section{Phylogenetic analysis}

On the entire set of available strains composed by original Cyanospira spp. strains and newly 
isolated strains, a phylogenetic analysis based on sequences of the 16S rRNA gene has been performed as described in Materials and Methods. Sequences of Cyanospira were added to a large alignment of Nostocaceae including 21 sequences of Anabaenopsis spp., 62 sequences of Nodularia spp. and 377 sequences of other Nostocaceae. Using ARB, a first Neighbour Joining (NJ) tree was inferred on the complete set of 472 sequences (data not shown). All strains of Cyanospira, either from the Rift Valley or from the Lake Chad region, clustered together in a monophyletic assemblage belonging to the Nostocaceae; the results also showed the separation of the sequences of Cyanospira spp. from those of Anabaenopsis spp. and their respective placement into two sister branches, having the monophyletic Nodularia branch as nearest relative. This finding confirmed and extended the observation by ITEMAN and colleagues (2002) that Cyanospira has a separate phylogenetic standing from Anabaenopsis.

In a following step, a smaller alignment including only Cyanospira spp., Anabaenopsis spp., and Nodularia spp. has been used as detailed in Materials and Methods. NJ, MP, and ML methods of phylogenetic inference have been applied to obtain phylogenetic trees. The phylogenetic trees obtained from the three different approaches were nearly identical and congruent and therefore only a consensus tree with the NJ topology is reported in Fig. 4 along with bootstrap percentages. The analysis clearly showed the existence of two sister clusters, Cyanospira and Anabaenopsis, that were either well distinct and closely related. Their stable existence is supported by very high bootstrap percentages. All analysed strains of Cyanospira and Anabaenopsis belonged to their respective branches. The Anabaenopsis branch was subdivided into two subclusters, both supported by bootstrap test. One of these subclusters included only strains of Anabaenopsis elenkinii and is a good candidate to represent the phylogenetic allocation of the species $A$. elenkinii itself; the other subcluster hosted sequences of various attribution, but inside it, two strains previously identified as members of the freshwater species A. nadsonii (Mugnai et al. 2008) showed a remarkable degree of relatedness and a high bootstrap support. Congruent data have been reported by BALLOT et al. (2008) on the same set of $A$. elenkinii strains, where it appeared that the phylogenetic separation between the two subclusters of Anabaenopsis could be paired by differences in the habitat of origin of the strains. Although the Cyanospira cluster could be subdivided in two subunits, respectively corresponding to the species $C$. rippkae and $C$. capsulata, the internal branching, showed in Fig. 4, lacked a complete bootstrap support. A subcluster including sequences of Cyanospira rippkae from Lake Magadi, newly isolated sequences of Cyanospira spp. from natron, and five nearly identical sequences of Anabaenopsis abijatae was clearly present in MP and ML analyses, and was supported by bootstrap test in the MP tree, while with $\mathrm{NJ}$, the existence of a separate subcluster housing C. capsulata was not fully supported. Also in the case of the Cyanospira branch, BALLOT et al. (2008) obtained comparable results, but due to the fact that their sequence set did not contain any representative of the species $C$. capsulata, those authors were not able to show that Anabaenopsis cf. abijatae strain AB2002/25 was a close relative to $C$. capsulata and not to C. rippkae.

As regards the species attribution of the strains included in the Cyanospira rippkae subcluster, one should notice that the species $A$. abijatae has been described as a true extremophile thriving in hyperalkaline saline habitats (BALLOT et al. 2008). The unique good reason to keep strains of $A$. abijatae separated from strains of $C$. rippkae would be the true branching behaviour observed in cultures of $A$. abijatae by BALLOT et al. (2008), that we were not able to observe in cultures of our strains. One should nevertheless notice that growing conditions and cultivation media in which the branching behaviour had been observed by BALLOT et al. (2008) were different from those applied in our experimental sets. For the rest, other ecological and morphological characters were quite congruent between strains of A. abijatae described by BALLOT et al. (2008) and strains of Cyanospira spp. described in this work. Therefore, we herewith propose that all strains included in the subcluster of the phylogenetic analysis belong to the species $C$. rippkae.

For habitat of isolation, growing conditions, cell and filament morphologies (Fig. 1), and life cycle (Figs 2-3), newly isolated cyanobacteria from natron described in this work definitely resembled species of Cyanospira previously described (FLorenzano et al. 1985). Morphometric data of the strains compared with data of the original Cyanospira capsulata Mag I 504 and C. rippkae Mag II 702, were presented in Table 
1. Morphometric variations between strains of Cyanospira isolated in 1981 and 1982 from Lake Magadi(Kenia) and strains of Cyanospira presently isolated from natron of the Lake Chad region are minor and negligible, the main differences being a slight increase of cell dimensions in Cyanospira sp. NMBCl and in Cyanospira sp NR3Af; a higher number of aerotopes in Cyanospira sp. $\mathrm{NMBCl}$; and an increased akinete differentiation in Cyanospira sp. strains 5NR8, 7NR8 and 8NR8.

All the isolated strains differed from species of Anabaenopsis since they did not show the diacritic features of this genus like the double heterocyte and cylindrical or oval akinetes generally much larger than vegetative cells (KOMÁREK 2005); instead, the akinetes of our isolates were spherical, in long rows and with slightly larger dimensions than those of vegetative cells.

Following results of phylogenetic analysis, strains 7NR8, NMBCl, 8NR8, 5NR8, and NR3Af could be assigned to the species $C$. rippkae; strain 9NAT could be assigned to the species $C$. capsulata.

As a consequence of the identification of the natron strains as members of the genus Cyanospira and of the assignment of strains of $A$. abijatae to the species $C$. rippkae, the description of the genus Cyanospira should be emended as follows.

The genus Cyanospira is characterised by trichomes solitary, planktic, more or less regularly screw-like coiled with coils $15-35 \mu \mathrm{m}$ wide, constricted at cross-walls, mucilaginous envelopes (capsule) more or less present (Fig. $2 \mathrm{a}-\mathrm{b})$. Cells shortly cylindrical, 4-8 $\mu \mathrm{m}$ wide, with numerous aerotopes (Fig. 2c-d). Single apical and intercalary heterocytes spherical, 6-9.8 wide. Akinetes spherical, in rows, $7-11 \mu \mathrm{m}$ wide, with typical apoheterocytic development (Fig. 2e-f) that starts from the vegetative cells in the middle between two heterocytes and later change all or almost all vegetative cells into akinetes, towards the heterocytes. Sometime, in adverse conditions, the entire trichome can differentiate into a chain of akinetes (Fig. $2 \mathrm{~g}-\mathrm{h}$ ).

\section{Discussion}

Morphological, life cycle and phylogenetic evidences strongly support the existence of the two sister genera Anabaenopsis and Cyanospira
(KomÁreK 2010). Genus Cyanospira is without any doubt representative of organisms adapted to hyperalkaline and saline habitats, such as soda lakes of Chad and of Rift Valley. It could be also hypothesised that the adaptation of Cyanospira to hyperalkaline conditions is a case of secondary adaptation to an extreme environment, since the branching between Anabaenopsis and Cyanospira occurred relatively recently as it can be inferred from its limited depth in the heterocytous cyanobacterial radiation (ITEMAN et al. 2002). Even if the genus Anabaenopsis does not include only truly freshwater species, specialised physiological adaptations needed to survive alkaline conditions and desiccation, like the massive development of very resistant and long lasting akinetes up to a complete transformation of vegetative filaments into chains of akinetes, were never observed in strains of any species of Anabaenopsis. We therefore consider that the peculiar extreme habitat conditions given by high $\mathrm{pH}$, high values of salinity, temperature and light irradiance, along with the need to survive prolonged desiccation periods in salt precipitates and to rapidly regain an active vegetative stage at the onset of more favourable conditions, acted as a driver for adaptation and evolution of a sister branch that recently separated from the mesophilic genus Anabaenopsis. A corresponding evolutionary pattern of adaptation was also shown by other couples of sister genera of cyanobacteria, where one of the two members is mesophilic, while the other is well adapted to extreme life conditions. The best known example is the couple of sister genera given by Cyanothece and its halophilic counterparts Halothece and Euhalothece (GARCIA-Pichel et al.1998; MARGHERI et al. 2008) which can be typically found in sea salt brines and salterns (MARGHERI et al. 1999). The physiological adaptation which differentiated these genera is the ability to grow faster at unusually high salt concentrations. Other very similar examples are the couples formed by Spirulina TURPIN ex GOMONT and its halophilic counterpart Halospirulina NüBel, GarCia-Pichel et MuYzer (NüBel et al. 2000; MARGHERI et al. 2003); and Phormidium KütZING ex Gomont compared with the halophilic counterpart Halomicronema ABED, Garcia-Pichel et HernándeZ-Mariné (ABed et al. 2002). Although the recently described genus Coleofasciculus Siegesmund, J.R. Johansen et FriedL (SIEGESMund et al. 2008) presently includes only the species C. chthonoplastes (ThuR. ex Gomont) Siegesmund, J.R. Johansen et Friedl, a 
phylogenetic analysis showed the existence of two distinct lineages inside it (SIEGESMUND et al. 2008). The lineages, that could not be distinguished by morphology, were constituted by strains with different salt requirements, lineage A occurring from salt marshes to hypersaline lakes, lineage B occurring in lower salinity brackish waters.

In conclusion, the differentiation of couples of sister genera in response to strongly selective conditions given by high salinity and extreme $\mathrm{pH}$ is a well represented evolutionary mechanism in cyanobacteria. Such sister cyanobacterial genera have developed specialised physiological adaptations to their respective extreme environments, while maintaining substantially common morphological traits with their mesophilic counterparts. The genus Cyanospira, having to survive a composite set of extreme environmental conditions, also developed a peculiar strategy of resistance to drought, such as the complete transformation of the filaments into chains of akinetes, which enables its recognition also on the basis of a unique morphological trait.

\section{References}

Abed, R.M.M., Garcia-Pichel, F. \& HernándeZMARINÉ, M. (2002): Polyphasic characterization of benthic, moderately halophilic, moderately thermophilic cyanobacteria with very thin trichomes and the proposal of Halomicronema excentricum gen. nov., sp. nov. - Arch. Microbiol. 177: 361-370.

Ballot, A., Dadheech, P.K., HaAnde, S. \& Krienitz, L. (2008): Morphologicaland phylogeneticanalysis of Anabaenopsis abijatae and Anabaenopsis elenkinii (Nostocales, Cyanobacteria) from tropical inland water bodies. - Microb. Ecol. 55: 608-618.

Cuzman, O.A., Ventura, S., Sili, C., Mascalchi, C., Turchetti, T., D’AcQui, L.P. \& Tiano, P. (2010): Biodiversity of phototrophic biofilms dwelling on monumental fountains. - Microb. Ecol. 60: 81-95.

Florenzano, G., Sili, C., Pelosi, E. \& Vincenzini, M. (1985): Cyanospira rippkae and Cyanospira capsulata (gen. nov. and spp. nov.): New filamentous heterocystous cyanobacteria from Magadi lake (Kenya). - Arch. Microbiol. 140: 301-306.

Garcia-Pichel, F., Nübel, U. \& Muyzer G. (1998): The phylogeny of unicellular, extremely halotolerant cyanobacteria. - Arch. Microbiol. 169: 469-482.

Gordon, D. (2004): Viewing and editing assembled sequences using Consed. - In: BaXevanis, A.D. \& Davison, D.B. (eds): Current protocols in bioinformatics, 1-43, John Wiley \& Co, New York, USA.

Grant, W.D. (2006): Alkaline environments and biodiversity. - In: GERDAY, C. \& GlansDORFF, N. (eds): Extremophilies. In: Encyclopedia of Life Support Systems (EOLSS), Developed under the Auspices of the UNESCO, Eolss Publishers, Oxford ,UK.

Iteman, I., Rippka, R., Tandeau de Marsac, N. \& Herdman, M. (2002): rDNA analyses of planktonic heterocystous cyanobacteria, including members of the genera Anabaenopsis and Cyanospira. - Microbiology 148: 481496.

KomÁrek, J. (2005): Phenotype diversity of the heterocytous cyanoprokaryotic genus Anabaenopsis. - Czech Phycology 5: 1-35.

KomÁreK, J. (2010): Modern taxonomic revision of planktic nostocacean cyanobacteria: a short review of genera. - Hydrobiologia 639: 231243.

Ludwig, W., Strunk, O., Westram, R., Richter, L., Meier, H., Yadhukumar, Buchner, A., Lai, T., Steppi, S., Jobb, G., Förster, W., Brettske, I., Gerber, S., Ginhart, A.W., Gross, O., Grumann, S., Hermann, S., Jost, R., König, A., Liss, T., Lüssmann, R., May, M., Nonhoff, B., Reichel, B., Strehlow, R., Stamatakis, A., Stuckmann, N., Vilbig, A., Lenke, M., Ludwig, T., Bode, A. \& Schleifer, K.H. (2004): ARB: a software environment for sequence data. - Nucleic Acids Res. 32: 1363-1371.

Margheri, M.C., Bosco, M., Giovannetti, L. \& VEnturA, S. (1999): Assessment of the genetic diversity of halotolerant coccoid cyanobacteria using amplified 16S rDNA restriction analysis. - FEMS Microbiol. Lett. 173: 9-16.

Margheri, M.C., Piccardi, R., Ventura, S., Viti, C. \& GiovannetTi, L. (2003): Genotypic diversity of oscillatoriacean strains belonging to the genera Geitlerinema and Spirulina determined by $16 \mathrm{~S}$ rDNA restriction analysis. - Curr. Microbiol. 46: 359-364.

Margheri, M.C., Ventura, S., KaštovskÝ, J. \& KomÁREK, J. (2008):The taxonomic validation of the cyanobacterial genus Halothece. Phycologia 47: 477-486.

Mugnai, M.A., Margheri, M.C., Sili, C., Turicchia, S., Soldati, E., Maffettone, E., Funari, E., Scardala, S., Di Brizio, M. \& Ventura, S. (2008): The cyanobacterial community of Lake Trasimeno. - Algological Studies 128, 37-64.

Nübel, U., Garcia-Pichel, F. \& Muyzer, G. (2000): The halotolerance and phylogeny of cyanobacteria with tightly coiled trichomes (Spirulina Turpin) and the description of Halospirulina tapeticola 
gen. nov., sp. nov. - Int. J. Syst. Evol. Microbiol. 50: 1265-1277.

Pruesse, E., Quast, C., Knittel, K., Fuchs, B., Ludwig, W., Peplies, J. \& Glöckner, F. O. (2007): SILVA: a comprehensive online resource for quality checked and aligned ribosomal RNA sequence data compatible with ARB. - Nucleic Acids Res. 35: 7188-7196.

Siegesmund, M.A., Johansen, J.R., Krsten, U. \& FriedL, T. (2008): Coleofasciculus gen. nov. (Cyanobacteria): morphological and molecular criteria for revision of the genus Microcoleus Gomont. - J. Phycol. 44: 1572-1585.

Sili, C., Ena, A., Materassi, R. \& Vincenzini, M. (1994): Germination of desiccated aged akinetes of alkaliphilic cyanobacteria. - Arch. Microbiol. 162: 20-25.
ZARrouk, C. (1966): Contribution à l'étude d'une Cyanophycée. Influence de divers facteurs physiques et chimiques sur la croissance et la photosynthèse de Spirulina maxima (Setchell et Gardner) Geitler. [PhD Thesis]. - pp., University of Paris, France.

(C) Czech Phycological Society (2011)

Recieved Sept 2010

Accepted Dec 2010 